\title{
The impact of economic and social human rights in New Zealand case law
}

\author{
Margaret Wilson, Judy McGregor and Sylvia Bell*
}

\begin{abstract}
Although New Zealand has traditionally relied on ' progressive realisation' of economic, social and cultural rights (ESCR) through public policy decision-making, recently there has been small number of cases relying on international human rights treaties, including the International Covenant on Economic, Social and Cultural Rights (ICESCR), to support the legal argument. This article reviews the implementation of the ICESCR in New Zealand through an analysis of this case law. The article argues that although there has been an increase in the number of cases relying of ESCR, the courts have been reluctant to grant a remedy without ESCR being explicitly incorporated into the domestic law. The article further argues that the attempt to provide a remedy for ESCR through the declaration of inconsistency under the Human Rights Amendment Act 2001 has highlighted the need for the inclusion of ESCR into the New Zealand Bill of Rights Act 1990.
\end{abstract}

Key words: ICESCR, New Zealand, public policy, case law

\section{Introduction}

This article is the result of research undertaken as part of a larger project to assess the impact of six human rights treaties on law and public policy. ${ }^{1}$ One of the treaties examined was the International Covenant on Economic, Social and Cultural Rights (ICESCR). Part of the analysis of the ICESCR was a review of the case law in which there was reference to or reliance on the ICESCR. This review recognises that New Zealand governments have relied on public policy expressed through general Acts of Parliament such as the Education Act 1989, New Zealand Public Health and Disability Act 2000, Social Security Act 1964 and Housing Corporation Act 1974 for compliance with the ICESCR. New Zealand governments have argued that New Zealand has interpreted its commitments under ICESCR as devising and developing administrative systems, policies and legislation as the most appropriate way by which to implement its obligations under the Convention. In effect, New Zealand has argued that the best way to implement economic, social and cultural rights (ESCR) obligations is through institutionally establishing a legislative and policy framework that sets a standard for all citizens to have access to ESCR.

\footnotetext{
${ }^{1}$ Faultline: Human Rights in New Zealand, McGregor, Bell and Wilson (2015) http:www.lawfoundation.org.nz/wp-content/uploads/2015/04/2011_38_17-public-version-ofResearch-Report-embargoed-till-2.4.15.pdf
} 
Some of the difficulties in developing a standards-based approach to ESCR derive from the ICESCR itself. Article 2(1) of the ICESCR states:

Each party to the present Covenant undertakes to take steps, individually and through international assistance and co-operation, especially economic and technical, to the maximum of its available resources, with a view to achieving progressively the full realisation of the rights recognised in the present Covenant by all appropriate means, including particularly the adoption of legislative measures. $^{2}$

The importance attached to the concept of progressive realisation was emphasised by the UN Committee monitoring the ICESCR when it noted that it:

... is of particular importance to a full understanding of the Covenant and must be seen as having a dynamic relationship with all of the other provisions. It describes the nature of the general legal obligations undertaken by State Parties to the Covenant. [CESCR 1990.]

It has been noted by Felner (2009), however, that governments may use the notion of progressive realisation as an 'escape hatch' to avoid complying with their human rights obligations - claiming, for instance, that the lack of progress is due to insufficient resources when, in fact, the problem is often not the availability but rather the distribution of resources. He also notes that the obligation of progressive realisation reflects that adequate resources are a crucial condition for the realisation of ESCR and the contingent nature of a state's obligations, implying that they may vary from one state to another depending on the state's economic development (Felner 2009, 402-35).

Although states are not obliged to incorporate ESCR into domestic law, the UN Committee on Economic, Social and Cultural Rights has stated that 'in many instances legislation is highly desirable and in some cases may even be indispensable', and that 'whenever a Covenant right cannot be made fully effective without some role for the judiciary, judicial remedies are necessary' (CESCR 1990, 3, 9). The issue for New Zealand then is whether the time has come to recognise that progressive realisation through a standards approach should be supplemented by the incorporation of ESCR into the New Zealand Bill of Rights Act 1990 (NZBORA).

The argument that ESCR are not justiciable is not a conclusive argument for the state to decline to legislate for ESCR. Similarly, the accompanying argument that the cost of implementing ESCR is uncertain and maybe prohibitive is not a sufficient justification for a blanket denial of legal recognition. The Committee on Economic, Social and Cultural Rights states that:

... a failure to remove differential treatment on the basis of lack of available funds is not an objective and reasonable justification unless every effort has been made to use all resources that

${ }^{2}$ The notion of progressive realisation is also referred to in Art 4 of the Convention on the Rights of the Child and in Art 4(2) of the Convention on the Rights of Persons with Disabilities. 
are at a State party's disposition in an effort to address and eliminate the discrimination, as a matter of priority. [CESCR 1990, 13.]

In the report of the latest Universal Periodic Review on New Zealand, there are several recommendations relating to the inclusion of ESCR within the NZBORA or a Human Rights Charter (Human Rights Council 2014, 128.30, 128.31. 128.32, 128.33, $128.34,128.35)$. In its response to the report, the government rejected the recommendations to include the ICESR in a Bill of Rights, to ratify the Optional Protocol to the ICESCR, and to continue the conversation on ESCR recommended by the Constitutional Advisory Panel $^{3}$ (New Zealand Government 2014).

This resistance was evident when the government declined to incorporate ESCR into the NZBORA. The notion of amending the NZBORA to include ESCR has recently been revived during the Constitutional Conversation (Constitutional Advisory Panel, 2013). There has also been recently a few high profile cases that have highlighted attempts by litigants to pursue their ESCR through litigation. This article will review the arguments for and against incorporation of ESCR into the NZBORA, as well as recent attempts to gain greater legal recognition of ESCR through legislation and the courts.

\section{New Zealand context}

The impact of the ICESCR on New Zealand policy and law has lacked the same level of analysis that has been given to civil and political rights under the International Covenant on Civil and Political Rights (ICCPR). Claudia Geiringer and Matthew Palmer, in their research paper 'Human rights and social policy in New Zealand' $(2007,12)$, noted that while there has been an increased interest from both inside and outside government in the impact of human rights generally, there is also considerable uncertainty about what a rights-based approach requires to social policy issues, primarily because of the difficulties in establishing the scope and effect of the obligations. The recent Constitutional Conversation initiated as a result of a coalition agreement between the National Party and the MāoriParty in 2008 has renewed interest in the legal recognition of economic social and cultural rights. The recent New Zealand Law Journal article by Baird and Pickard argued:

... in favour of some variant of the second model of constitutionalising ESCR, namely, one which accords ESCR equivalent status to civil and political rights, which enables them to be a check and balance on the development of policy and legislation, and which is directly enforceable in the courts. [Baird and Pickard 2013, 292.]

\footnotetext{
${ }^{3}$ The Constitutional Advisory Panel was established as the result of a coalition agreement between the National Party and the MāoriParty at the 2008 election to engage with the public on constitutional change. The Panel recommended a further constitutional conversation on several issues, including ESCR.
} 
The editorial in the same issue responded to the article disputing the status of ESCR as human rights, which in turn prompted a response from Opie, who concluded his defence of the ESCR with the statement:

ESCR are internationally recognised, legally binding human rights, and this has been long accepted by New Zealand. The fundamental interests they represent are well-known here and aspects of them are protected by legislation. Far from being unrealistic, ESCR are reasonable rights, capable of implementation and judicial enforcement. [Opie 2014, 195.]

\section{Legal arguments relating to incorporation of ESCR}

Reluctance to incorporate ESCR into legislation is founded on two underlying arguments. The first argument rests on the so-called hierarchy of rights concept, by which critics of ESCR view them as inherently distinct from other 'real rights' contained in the ICCPR. Opponents of the justiciability of ESCR suggest that because they are subject to progressive realisation, they are not legal rights but aspirational goals only. This hierarchy of rights view is reinforced by the difficulties of bringing to court cases involving progressive realisation when they are linked to the allocation of resources on which judges are often reluctant to make judgment because they are seen as the prerogative of the government of the day. The International Commission of Jurists (2008) notes too that cases involving ESCR are often difficult to bring to court because they can rely on proving causal links between inadequate progress on the enjoyment of a specific right and state action or inaction, and such causal links may be neither available nor admissible in courts. (International Commission of Jurist 2008).

In the New Zealand context, legal remedy for breach of human rights obligations may be pursued through judicial review or reference to a tribunal such as the Human Rights Review Tribunal. Judicial review provides a limited remedy because it deals only with process and not with the substance of the policy incorporated within the legislation. There is therefore a very limited opportunity for citizens to legally challenge whether the legislation is consistent with the obligations undertaken under the ICESCR.

The limited nature of the opportunity to challenge government policy through the judicial review process was illustrated in the case Daniels v Attorney-General, 2002. This case involved a judicial review of the special education policy introduced by the Minister of Education in 1998. Essentially, the plaintiffs argued that their children should have a choice of attending special education facilities where mainstreaming was inappropriate or ineffective. The policy had disestablished special education facilities and the argument was that this policy was in breach of $s 3$ (right to free primary and secondary education), s 8 (equal rights to primary and secondary education) and s 9 (right to provision for special education if qualified) of the Education Act 1989. Although the High Court decision held that there had been a breach of the children's right to an education, the Court of Appeal overturned the 
decision on the grounds that the legal obligation on the state was to provide regular and systemic education, and this general obligation was not justiciable though specific rights may be actionable under the Act. Justice Keith noted that 'while there are rights under the 1989 Act that can be enforced by court process [such as natural justice on suspension and expulsion], these rights do not include generally and abstractly formulated rights of the kind stated by the [High Court] Judge' (at [83]). The court also noted the difficulty presented for judicial supervision of enforcement of general standards of education, such as was argued in this case. Justifiability then was an issue in this case and the court drew a line between specific individual rights and general rights incorporated into the Act.

The important influence of judicial culture has been analysed in the context of the NZBORA by David Erdos $(2009,95)$. He argues that both the cultural selfperceptions of the judiciary and the context within which NZBORA has been implemented are relevant to gaining an understanding of why the judicial response has been relatively conservative and mainly directed to the implementation of civil and political rights. He concludes:

\footnotetext{
Other than judicial culture itself, factors of particular importance within this structure include the nature of the NZBORA enactment and remedies available under it, the attitude of the political branches to the agenda of divergent social actors ... and the political and legal resource set of the same actors. [Erdos 2009, 96.]
}

The importance of the political and policy environment on the construction of ESCR state obligations and its influence on the judicial approach to these issues has been explored by Opie in a more recent article $(2012,473)$. He has argued that the changes in public policy since 1984 have detrimentally affected the ESCR of citizens. In support of his argument, Opie analyses the case of Lawson $v$ Housing New Zealand, 1997, in which Mrs Lawson, a state tenant, sought a judicial review of the Minister of Housing decision to transfer state houses to a private company that then introduced market rents, resulting in a rise of over 100 per cent. Among the arguments in support of the judicial review was that the policy was in breach of s 8 of the NZBORA relating to a right to life, as well as the government's obligations under international treaties including ICESCR. The action was dismissed in the High Court, with the judge giving, among other reasons, that the facts required an unduly strained interpretation of s 8 and that, anyway, s 5 applied, as the policy and actions were a reasonable limit on the rights of Mrs Lawson. Basically, the judge argued that the decision on rents was a purely commercial decision over which the court had no jurisdiction and the action was therefore outside the scope of judicial review. In other words, the issue was not justiciable.

Opie further states that inclusion of ESCR in the NZBORA would have enabled citizens to be educated on the importance of both their civil and political and their economic, social and cultural rights and freedoms, and would have provided an influence on policymakers to uphold those rights and freedoms. He argues: 
All of these reasons providing [civil and political rights] with a special status in the NZBORA applied with equal force to ESCR (and continue to apply today) ... The inclusion of ESCR in the NZBORA could have slowed the pace of the reforms: tempted their severity by contributing to a more cautious approach from the outset; encouraged more robust and evidence-based policy; promoted ESCR through expressly requiring ESCR-consistent interpretations of legislation where such interpretations were open; and led to the identification of conduct that was inconsistent with ESCR (thereby protecting and upholding these rights). Justiciable ESCR could have provided an important and democratic check on the State's power, particularly given the context of democratic failure in which the reforms occurred. [Opie 2012, 501-02.]

While there has been a relatively conservative approach to exploring the potential and opportunities provided for the implementation of social and economic rights by policymakers and the judiciary, recently there has been a renewal of social and litigation activism attempting to give practical and legal meaning to ESCR. It would be inaccurate to suggest that a coherent policy approach has emerged from governments, or that the judiciary has adopted an activist role in the implementation of economic and social rights. There is evidence, however, of recognition of serious issues of social and economic inequality that have arisen from the adoption of the current neo-liberal policy framework. ${ }^{4}$

This evidence is seen in the number of cases being initiated by the Human Rights Commission (Ministry of Health $v$ Atkinson, 2012); trade unions, in particular the Service and Food Workers Union (Service and Food Workers Union Nga Ringa Tota Inc $v$ Terranova Home and Care Ltd, 2013); and NGOs, such as the Child Poverty Action Group (Child Poverty Action Group Incorporated $v$ Attorney-General, 2013) that have required the government and the courts to address economic and social issues. A review of the difficulties of sustaining a legal challenge to the implementation of ESCR will be undertaken later in this article. Mike Darke undertook a review of

${ }^{4}$ The debate on inequality in New Zealand is reflected in Question Time in the Parliament in Inequality, Economic and Social-Rate Over Last 30 Years and Inequality, Economic and Social-Income Gap, www.parliament.nz. 30 January 2014, vol 696, p 15694 
ESCR cases in 2011, so the cases referred to in this article are subsequent to his analysis (Darke 2011, 63).

Although the ICESCR has not been formally legally recognised, this does not mean that the courts are unable to rely on the provisions of the treaty if a relevant issue comes before the courts. In New Zealand Air Line Pilots Association Inc v AttorneyGeneral, 1997, the Court of Appeal held that:

We begin with the presumption of statutory interpretation that so far as its wording allows legislation should be read in a way which is consistent with New Zealand's international obligations ... That presumption may apply whether or not the legislation was enacted with the purpose of implementing the relevant text ... In that type of case national legislation is naturally being considered in the broader international legal context in which it increasingly operates. [At 269, 293.]

A recent application of this principle is found in Service and Food Workers Union Nga Ringa Tota Inc $v$ Terranova Homes and Care Ltd, where the judgment of the Full Court noted:

Statutes should be interpreted in a manner that is consistent with New Zealand's international obligations. While international obligations cannot affect the meaning of statutory words that are clear, they may influence the interpretation adopted where they are open to different meaning. [At 157 [56].]

In this case, the Employment Court was determining a number of preliminary issues relating to the scope of any subsequent inquiry conducted under s 9 of the Equal Pay Act 1972. In essence, the Service and Food Workers Union (SFWU) was bringing a pay equity claim on behalf of care workers. In the course of the judgment, the court referred to the International Labour Organization's (ILO's) Convention Concerning Equal Remuneration for Men and Women Workers of Equal Value (Convention 100), which had been ratified by New Zealand in 1983. The court also considered Art 7 of the ICESCR, relating to fair wages and equal work for equal value, and Art 11 of the Convention on the Elimination of All Forms of Discrimination against Women (CEDAW), which requires the elimination of all discrimination against women in employment and, in particular, the right to equal remuneration and equal treatment in respect of work of equal value. The court decided, among other matters, that it had jurisdiction to state general principles for the implementation of equal pay.

The Employment Court judgment, however, implicitly, if not explicitly, acknowledges progressive realisation of ESCR. The court said:

History is redolent with examples of strongly voiced concerns about the implementation of anti-discrimination initiatives on the basis that they will spell financial and social ruin, but which proved to be misplaced or have been acceptable as the short term process of the longer term social good. The abolition of slavery is an old example, and the prohibition on discrimination in employment based on sex is both a recent and particularly apposite example. [At [110].] 
The Employment Court decision was appealed to the Court of Appeal, which dismissed the appeal (Terranova Homes and Care Ltd $v$ Service and Food Workers Union Nga Ringa Tota, 2014). In the course of the judgment, the court affirmed:

It is now settled law that there is an interpretative presumption that Parliament does not intend to legislate contrary to New Zealand's international obligations. [At [227].]

In support of this statement, the Court of Appeal cited not only the New Zealand Air Line Pilots Association but also Ye v Minister of Immigration, 2010; Zaoui v AttorneyGeneral (No 2), 2006; and Sellers v Maritime Safety Inspector, 1992. This principle would appear to be now firmly established in New Zealand.

The Court of Appeal, however, decided that its decision placed less weight on ILO Convention 100 and the Bill of Rights than did that of the Employment Court and relied primarily on the language and purpose of the Equal Pay Act itself.

The SFWU pay equity case highlights that the fact that ESCR are to be found in ILO conventions, as well as in the UN human rights treaties. The Employment Relations Act 2000 makes specific reference to ILO Conventions 87 and 98. Reference by the courts to ILO conventions has also been observed in recent decisions in the European Court of Human Rights (Demir and Baykara v Turkey, 2008). New Zealand was a founding member of the ILO and ratified many of the ILO conventions. Although the former industrial conciliation and arbitration system functioned as a closed 'legal' system, since the enactment of the Employment Contracts Act 1991 and the Employment Relations Act, employment rights are now subject not only to employment statutes, but also to the common law and international conventions in a way that has not happened in the past. The construction of employment rights as human rights has opened a new line of argument in litigation. Miller and Sissons (2013) argue that both the ICPCR and the ICESCR are relevant to the enforcement of employment rights, including the right to collective bargaining

In a recent review of international law and New Zealand over the past 50 years, Sir Kenneth Keith comments on recommendations made by the Human Rights Committee in 2010 and the Committee on Economic, Social and Cultural Rights in 2012 to the effect that concern was expressed over the fact the NZBORA does not take preference over ordinary law, and that the NZBORA does not incorporate ESCR. He notes in response to these recommendations:

Perhaps the question may be asked is whether the committees are giving more weight than is appropriate to form rather than to substance, or in legal terms, to obligations of means rather than of result ... Whatever the answer to the question I have asked may be, the process does have the real value to the wider legal and administrative system of emphasising an overall view. In particular, it helps emphasise the link between international law and constitutional law ... [Keith 2013, 719, 736.]

Sir Kenneth's comment reflects the traditional judicial reluctance to incorporate ESCR into the NZBORA. It also, however, acknowledges the constitutional reality 
that New Zealand has ambivalence to judicial decision-making on matters that are considered political. Sir Geoffrey Palmer more explicitly rejects the incorporation of ESCR into the NZBORA after a consideration of possible reform of the NZBORA. He states:

I do not see judicial encroachment into key government activity would be acceptable in New Zealand and neither does it seem to me necessary or desirable. It runs contrary to our traditions and our political culture. Neither do I believe our judges have the background or capacities to make that sort of decision ...These issues are properly the stuff of politics. Politics is about who gets what, when and how. Politics is the language of priorities and priorities should not be set by the courts. [G Palmer 2011, 286.]

\section{Constitutional arguments relating to the incorporation of ESCR}

The above comments are in opposition to the recent report of the Committee on the Elimination of Discrimination against Women (2012) and the Human Rights Council's Universal Periodic Review of New Zealand (2014), which recommended legal incorporation of human rights treaty obligations. As noted previously, UN monitoring bodies have also frequently referred to the need to incorporate ICESCR obligations into the NZBORA and this recommendation has been rejected by government. The primary reason for this position lies in the nature of New Zealand's constitutional culture and institutional arrangements. New Zealand has no written constitution or human rights legislation that overrides other Acts of Parliament. Parliamentary sovereignty is the foundation concept on which constitutional arrangements rest in New Zealand.

If there is to be any change in the New Zealand position to fully implementing obligations under the ICESCR, it will require a change in New Zealand's constitutional culture. As Matthew Palmer (M S R Palmer 2007, 565) has noted, New Zealand does not regard the rule of law as a fundamental constitutional value, and New Zealanders are sceptical about giving too much power or authority to the judges. The pragmatism that characterises New Zealanders' approach to their Constitution prefers to rely on political action, not litigation, to protect their wellbeing. Legal rights are seen as a last resort remedy when seeking an effective way to protect and further constitutional issues such as human rights.

Constitutional change then is required not only to recognise human rights as fundamental rights, but also to enable citizens to seek a remedy for a breach of these rights through the legal system. The NZBORA is the only appropriate statutory vehicle to carry into law ESCR and effectively implement the obligations New Zealand has undertaken under the ICESCR. An understanding of the challenges facing the necessary constitutional change requires a knowledge of the political context within which ESCR have developed. First, it is important to note that in the past there has always been a level of cross-party support for the recognition of ESCR. For example, during the discussions preceding the adoption of the Universal 
Declaration of Human Rights, New Zealand's representative argued for the inclusion of social and economic rights. The rationale for the position was described by Dr Aikman as follows:

My delegation ... attaches equal importance to all the articles ... At the same time we regard with particular satisfaction the place which is given in the declaration to social and economic rights. Experience in New Zealand has taught us that the assertion of the right of personal freedom is incomplete unless it is related to the social and economic rights of the common man. There can be no difference of opinion as to the tyranny of privation and want. There is no dictator more terrible than hunger. And we have found in New Zealand that only with social security in its widest sense can the individual reach his full stature. Therefore it can be understood why we emphasize the right to work, the right to a standard of living adequate for health and well being, and the right to security in the event of unemployment, sickness, widowhood and old age. Also the fact that the common man is a social being requires that he should have the right to education, the right to rest and leisure, and the right to freely participate in the cultural life of the community.

These social and economic rights can give the individual the normal conditions of life, which make for the larger freedom. And in New Zealand we accept that it is the function of government to promote their realization. [Aikman 1999, 5.]

This position reflected the fact that the Labour government that was elected in 1935 implemented a social security system that was designed to provide for economic and social well-being. In 1978, New Zealand ratified the ICESCR. New Zealand has yet to ratify the Optional Protocol to the Covenant. Ratification took place under a National government that at that time adopted a bipartisan approach to human rights, though the government lodged a reservation on the provision on the right to form and join a trade union on the grounds that the article conflicted with existing legislation in New Zealand. The reservation remains, though the legislative framework has radically changed since 1978.

At the time of ratification, there was a public policy consensus on the role of the state as the provider of social security of all citizens. The Human Rights Commission Act 1977 , which verified the ratification, had a limited coverage, with the grounds on which discrimination against individuals was unlawful being confined to sex, marital status, and religious and ethical belief. This reflected a general lack of concern that discrimination was a widespread issue within the community. Public policy provision for health, housing, education and social security through statutory frameworks aimed primarily at administration was considered to be the primary means by which the international obligation was fulfilled. It should also be noted that, at the time of ratification, the Equal Pay Act 1972 had been enacted and was progressively being implemented. More fundamentally, the Human Rights Commission Act reflected a negative as opposed to a positive approach to human rights. The right not to be discriminated against provided a more limited right than a positive right to equality. This approach reflected the longstanding preference for government to enact ESCR policies rather than create individual legal rights. 
There was a political consensus on the approach to the implementation of human rights in the 1970s that was challenged in 1984 with the election of the fourth Labour government. The ideological preference of this and subsequent governments has changed the public policy approach to these issues. There is now a preference for market as opposed to state responses to ESCR issues. As the focus in public policy shifted from state to individual responsibility for economic and social well-being, the question has arisen about what exactly were the rights of the individual and how were they to be implemented. A more fundamental question has also arisen that is beyond the scope of the article - namely, what is the role of government if it is not responsible for the outcomes of its policies?

New Zealand first confronted directly the issue of enacting fundamental human rights in legislation during the 1980s, with the debate of whether to enact a Bill of Rights. It was during this time that the question of whether ESCR should also be included in the Bill of Rights was raised. Ultimately, the government rejected the proposal to include ESCR on a variety of grounds, including that the Bill was to be primarily focused on constitutional and political rights that were characterised as being value-free negative rights that required the state to refrain from infringing those rights. The obligations on the state were therefore considered to be minimal.

ESCR, in contrast, were considered not to be value free and to impose specific obligations of the state that may change from time to time. As such, it was argued that the ESCR were uncertain and not justiciable and therefore better implemented through other legislative and administrative means (G Palmer 1984-85). The exclusion of ESCR from the NZBORA was supported by the then Minister of Justice, Geoffrey Palmer. However, in 2006, in a paper he delivered at a conference reviewing the Bill of Rights after 15 years, Palmer noted that while other jurisdictions, such as South Africa, had enacted ESCR within their constitution, he still held the view such issues were best left to politics (G Palmer 2006, 28-29). As noted previously, his concern appeared to relate to giving the judiciary the right to make what may be considered policy/political decisions.

The latest attempt to advocate for the inclusion of ICESCR into the NZBORA has taken place during the recent Constitutional Conversation initiated by the government as a result of a provision in the coalition agreement between the National Party and the Māori Party (Constitutional Advisory Panel 2013). The report of the Constitutional Panel observed that the incorporation of ESCR into the NZBORA was a common theme throughout the conversations. It recommended that a process be set up for a continuing conversation on further options for amending the NZBORA (Constitutional Advisory Panel 2013, 17). It is to be hoped that this conversation will continue and that New Zealand achieves formal legal 
incorporation of the ICESCR, whether it be through an amendment to the NZBORA or specific legislation. ${ }^{5}$

The prospect of any constitutional change in the near future appears unlikely. There is not only a lack of widespread public support for change, but also cross-party support for no change that would interfere with the notion of parliamentary sovereignty. In this context, it is relevant to note that public policy in New Zealand remains grounded on the notion of the withdrawal of the state from the provision of public services and the transfer of these services to the private or voluntary sector. The implications of this policy approach for the progressive realisation of the implementation of ESCR through public policy are yet to be fully understood. As the state gradually withdraws from the provision of economic, social and cultural services, the lack of effective legal remedy to enforce international treaty obligations is likely to become more apparent.

\section{A way forward - declaration of inconsistency}

In the face of the legal and constitutional reality of resistance to incorporation of ESCR into the NZBORA, the Human Rights Act 1993 has been relied on to justify New Zealand's ratification and partial compliance with ICESCR. The Act provides for the right not to be the subject of discrimination on specified grounds. The provisions of the Act have been subject to much analysis (Huscroft and Rishworth 1995; Butler and Butler 2006), so this review will focus on the relationship between the NZBORA and the 2001 Human Rights Amendment Act that attempted to provide a legal review of whether the state was fulfilling its legal obligations to implement human rights as stated in the Human Rights Act. The 2001 Amendment was a somewhat clumsy legislative attempt to provide a remedy for breach of rights in the Human Rights Act through reference to s 19 of the NZBORA - namely, the right to freedom from discrimination (Wilson 2011). It arose from the attempt by the Human Rights Commission in the 1990s to persuade the government to make the Human Rights Act superior law in the sense that all other legislation would be subject to compliance with that Act.

The election of a new government in 1999 provided the opportunity for the Reevaluation of the Human Rights Protections in New Zealand, a review of the human rights legislation, and to address the question of whether the Human Rights Act should be superior law (Ministry of Justice 2001). Although politically there was no possibility of enacting an amendment to make the Human Rights Act superior law

\footnotetext{
${ }^{5}$ The government response to the Universal Periodic Review (New Zealand
} Government 2014) makes this unlikely, however, as it has specifically rejected engaging in a further conversation on ESCR. 
because it would have required a fundamental review of New Zealand's constitutional arrangements, the review acknowledged that the NZBORA was the most appropriate legislation to be given this status. The review also recommended that when a person is acting under a statutory authority, their actions should be assessed against the NZBORA standard. This recommendation was enacted through a new Pt 1A of the Act giving the Human Rights Review Tribunal the power to issue a declaration that an enactment of a policy is inconsistent with the right to freedom from discrimination provided for in s 19 of NZBORA. The Minister responsible for the offending enactment is then required to report to Parliament the existence of the declaration and within 120 days of all appeals being heard must respond on what action it intended to take. The declaration did not declare the offending enactment invalid or require a change of policy. The right of Parliament to make the law and government policy was preserved under this arrangement, but it did provide a transparent process whereby human right breaches could be identified and made public (Hindle 2013). This legislative scheme was also an attempt to redress situations such as that that arose in the Lawson case, where a change in policy causes considerable harm to individual citizens who are entitled to a legal remedy that addresses their issue but preserves the constitutional notion of parliamentary sovereignty. In effect, the 2001 Amendment procedure was a back-door attempt to enable ESCR to be litigated in the tribunal and courts. It was an attempt at providing a remedy for breach of ESCR through the NZBORA right to be free from discrimination (s 19), while not explicitly incorporating ESCR within the law.

The Re-evaluation of the Human Rights Protections in New Zealand also recommended that the focus of the Human Rights Commission should be on education and advocacy, as well as being a complaints-driven institution. Importantly, the report also recognised that the primary means of implementation of many human rights obligations was through policymaking, and therefore it was essential to ensure that there was an integrated approach that included human rights obligations at an early stage of all policymaking (Ministry of Justice 2001, 94-96). A whole-of-government approach was required from the public service and governments to develop the rights-based approach to policymaking. In an attempt to gain the support of the public service, the Chief Human Rights Commissioner and the Associate Minister of Justice met individually with all the chief executives to explain the importance of adopting such an approach. The inclusion in the Cabinet Manual of the need for ministers to verify that the human rights implications of all policy papers to Cabinet had been taken into consideration was another attempt to develop a culture of respect for human rights within the public service policymaking process (Butler 2006). Geiringer and Palmer (2007) have demonstrated the limited success of these initiatives.

The first case under the Pt 1A jurisdiction was Howard $v$ Attorney-General (No 3), 2008 , bought by an individual litigant who challenged legislation under which 
people aged over 65 were no longer eligible for consideration for vocational rehabilitation after suffering personal injury. Royden Hindle, former Chairperson of the Human Rights Review Tribunal, describes the challenges facing individual litigants in pursuing this remedy and the important facilitative role of the tribunal and the commission to ensure that the matter was pursued professionally (Hindle 2013). Although a declaration of inconsistency was issued by the tribunal in Howard and it was acknowledged that the legislation would be amended to make it human rights compliant, the Crown elected to appeal the declaration through to the Court of Appeal. This stance by the Crown foreshadowed an adversarial approach to actions under Pt 1A in future cases. The Crown would appear to have ignored the intention of the legislation to provide a constructive conversation between the judiciary and the Parliament over human rights issues and to have adopted an aggressive stance against citizens pursuing their human rights.

Ministry of Health $v$ Atkinson, 2012, was the first substantive case under the Pt 1A procedure that has provided an opportunity to review how the 2001 Amendment works in practice, as well as providing a practical example of the difficulties associated with the current statutory regime. In this case, the tribunal issued a declaration of inconsistency in respect of an allegation of discrimination on the grounds of family status by a group of families who were denied financial support for the care of relatives with disabilities. After the Minister of Health received the declaration, an appeal was lodged with the High Court, which upheld the tribunal's decision, as did the Court of Appeal when the Ministry appealed the High Court decision. The government then decided not to appeal to the Supreme Court, but entered negotiations with the families to determine the payments to which they would be entitled.

The government also, however, introduced the New Zealand Public Health and Disability Bill (No 2) 2013. The Bill limited the Crown's liability to pay family members who provide support to their disabled family members. It also reasserted the right of the Crown and District Health Boards not to pay or fund family members to provide health and disability support, and that such a policy was not considered to be unlawful discrimination under the Human Rights Act. The Bill was enacted and is now law regardless of the s 7 NZBORA assessment that the Amendment authorised a breach of the non-discrimination right guaranteed by $\mathrm{s}$ 19(1) of the NZBORA. Further, the s 7 opinion noted that the legislation 'appears to limit the right to judicial review because it would prevent a person from challenging the lawfulness of a decision on the basis that it was inconsistent with s 19(1) of the Bill of Rights Act' (Attorney-General 2013).

In a subsequent case, Spencer $v$ Attorney-General, 2013, which related to the new New Zealand Public Health and Disability Act 2013 and the refusal of the Ministry of Health to consider Mrs Spencer's application for payment of disability support for her son, Justice Winkelmann held that the Ministry had acted unlawfully and in breach of 
Mrs Spencer's rights when it refused to consider her application, stating that it was acting in accordance with the new policy that was supported by the legislation. The case has been appealed by the Attorney-General, who is arguing that the court erred in its interpretation of both what is meant by a 'family care policy' and $\mathrm{Pt} 4 \mathrm{~A}$ of the Public Health and Disability Act 2013.

The response of government to legislate against decisions of the courts with which it does not agree also occurred in the case Harlen $v$ Chief Executive of the Ministry of Social Development, [2012] an appeal against conviction of offences relating to overpayment of social security benefits. One of the arguments advanced in support of the appeal was whether the Social Security Appeal Authority erred in law by failing to give sufficient consideration to the effects of ongoing reductions in benefit levels on the rights of the child under Arts 26 and 27 of the Convention on the Rights of the Child and the rights of citizens in need of social security for support under Art 27 of the Convention on the Rights of the Child and Arts 9-12 of the ICESCR. The court found that there had been a failure to take sufficient account of these provisions when the Authority made its decision. Subsequent to this decision and several other cases relating to debts incurred under the social security system, the Social Security (Fraud Measures and Debt Recovery) Amendment Bill was introduced and enacted. The legislation may make it more difficult to rely on international treaties to support actions before the courts.

The government's response to the declaration of inconsistency in the Atkinson case illustrates the earlier arguments that there is a fundamental resistance to curtailing the power of Parliament and governments to make policies and law, even if contrary to the human rights treaty obligations that form part of the New Zealand legal system. The issue is basically a constitutional issue, and without a change to the existing constitutional arrangements there is unlikely to be a recognition or incorporation of the ICESCR into New Zealand legislative framework. The constitutional nature of this legislation was discussed in the blog of constitutional legal academic Andrew Geddis, who started his commentary in the following way:

Our constitutional arrangements work on an implicit bargain - the principle of comity that the Courts and Parliament don't mess with each other's turf. I think that bargain just got broken. [Geddis 2013.]

Parliament had enacted legislation with the explicit intention of overturning the court decision that recognised that there had been a breach of human rights. While the notion of parliamentary sovereignty recognises the right of Parliament to legislate in such circumstances, the removal of any future right to bring an action for a breach of a statutorily recognised human right has caused considerable negative comment.

It would appear also that the government response to Atkinson might have influenced the approach of the courts when considering complaints of a breach of 
the NZBORA right to be free from discrimination. In Child Poverty Action Group Incorporated $v$ Attorney-General, the Child Poverty Action Group (CPAG) made a complaint to the Human Rights Tribunal that the in-work tax credit scheme constitutes discrimination on the basis of employment status. It argued that under $\mathrm{s}$ 21(1)(k) of the Human Rights Act, it is unlawful to discriminate against persons on the basis of their employment status - which includes the fact that the person is in receipt of a social security benefit. Although the tribunal considered that the eligibility rules for in-work tax credit were prima facie discriminatory, this was a justified limit under s 5 of the NZBORA, which provides that rights may be limited only to the extent reasonably necessary in a free and democratic society. CPAG appealed to the High Court, which rejected the appeal, as did the Court of Appeal when an appeal was made to that court. The Court of Appeal in its judgment acknowledged New Zealand's obligation under both the ICESCR and the Convention on the Rights of the Child, but held that under the NZBORA test the discrimination was justified. CPAG has decided not to appeal to the Supreme Court but to pursue the matter politically.

\section{Conclusion}

A review of the case law under the Human Rights Act suggests that until there is a clear statutory commitment to incorporate the Articles of ICESCR into the NZBORA, it will be very difficult to pursue economic and social rights through the courts in New Zealand. It has become clear that the inclusion of the ICESCR into the NZBORA is necessary to ensure effective and sufficient compliance with the obligations so that citizens have economic and social rights. The way forward for the implementation of ESCR has been summarised by Karen Meikle $(2011,62)$ as follows:

\footnotetext{
The best way forward for New Zealand will be an integrated approach, including constitutional recognition, the affirmation and promotion of the justifiability of ESC rights issues ... Knowledge and awareness will engender respect. To date ESC rights in New Zealand have not been given the exposure they require in order to equip participants with the requisite knowledge so that they can ensure the meaningful protection of such rights. ESC rights need to become part of mainstream thinking in New Zealand society in order for change, and those rights, to be accepted and realised. [Meikle 2011, 62.]
}

This approach is similar to that argued by Baird and Pickard (2013), who advocated that ESCR should be accorded the equivalent status of civil and political rights. This would enable sufficient checks and balances while enabling the rights to be tested in court. These approaches would seem a sensible prescription for implementation understanding and knowledge through education and transparency to enable constitutional change to recognise and include ESCR in both policymaking and the legal system. Greater knowledge is required too of the state party's obligations under Art 2 of the ICESCR to progressively realise rights to the maximum of 
available resources. If this obligation was better understood and articulated, it would allow improved domestic and international monitoring of progress, stasis and regression of ESCR in New Zealand.

\section{References}

\section{New Zealand cases}

Atkinson v Ministry of Health [2008] NZHRRT 1; Ministry of Health [2012] NZCA 184

Child Poverty Action Group Incorporated v Attorney-General [2013] NZCA 402

Daniels v Attorney-General [2002] 2NZLR 742

Harlen $v$ Chief Executive of the Ministry of Social Development [2012] NZAR 491

Howard v Attorney-General (No 3) (2008) 8 HRNZ 378

Lawson v Housing New Zealand [1997] 2 NZLR 474

Ministry of Health $v$ Atkinson [2012] NZCA 184

New Zealand Air Line Pilots Association v Attorney-General [1997] 3 NZLR 269

Sellers v Maritime Safety Inspector [1992] 2 NZLR 44 (CA)

Service and Food Workers Union Nga Ringa Tota Inc v Terranova Homes and Care Ltd [2013] NZEmpC 157

Spencer v Attorney-General [2013] NZHC 3 October 2013

Terranova Homes and Care Ltd $v$ Service and Food Workers Union Nga Ringa Tota [2014] NZCA 516

Ye v Minister of Immigration [2010] 1 NZLR 104

Zaoui v Attorney-General (No 2) [2006] NZLR 298

\section{European Court of Human Rights case}

Demir and Baykara v Turkey Application No 34503/97, 12 November 2008

\section{New Zealand legislation}

Education Act 1989

Employment Contracts Act 1991

Employment Relations Act 2000

Equal Pay Act 1972

Housing Corporation Act 1974

Human Rights Act 1993 
Human Rights Amendment Act 2001

Human Rights Commission Act 1977

New Zealand Bill of Rights Act 1990

New Zealand Public Health and Disability Act 2000

New Zealand Public Health and Disability Act 2013

New Zealand Public Health and Disability Bill (No 2) 2013

Social Security Act 1964

Social Security (Fraud Measures and Debt Recovery) Amendment Act 2013

Social Security (Fraud Measures and Debt Recovery) Amendment Bill

\section{International legal materials}

Convention on the Elimination of All Forms of Discrimination against Women, adopted 18 December 1979, entered into force 3 September 1981, 1249 UNTS 13

Convention on the Rights of Persons with Disabilities, 24 January 2007, A/RES/61/106

Convention on the Rights of the Child, adopted 20 November 1989, entered into force 2 September 1990, 1577 UNTS 3

International Covenant on Civil and Political Rights, adopted 16 December 1966, entered into force 23 March 1976, 99 UNTS 171

International Covenant on Economic Social and Cultural Rights, adopted 16 December 1966, entered into force 3 January 1976, 993 UNTS 3

International Labour Organization Convention Concerning Equal Remuneration for Men and Women Workers of Equal Value (Convention 100)

Optional Protocol to the International Covenant on Economic, Social and Cultural Rights, 5 March 2009, A/RES/63/117

\section{Other references}

Aikman C (1999) 'New Zealand and the origins of the Universal Declaration' 29 Victoria University of Wellington Law Review 1

Attorney-General (2013) Report of the Attorney-General under the New Zealand Bill of Rights Act 1990 on the New Zealand Public Health and Disability Amendment Bill (No 2) 16 May [Online] Available: www.parliament.nz/ennz/pb/legislation/bills/digest/50PlLaw20491/new-zealand-public-health-anddisability-amendment-bill accessed 16 June 2015

Baird N and Pickard D (2013) 'Economic, social and cultural rights: a proposal for a constitutional peg in the ground' (September) New Zealand Law Journal 289 
Bedggood M and Gledhil K (eds) (2011) Law into Action: Economic, Social and Cultural Rights in Aotearoa New Zealand Human Rights Foundation of Aotearoa, Auckland

Butler A and Butler P (2006) The New Zealand Bill of Rights Act: A Commentary LexisNexis, Wellington

Butler P (2006) '15 years of the NZ Bill of Rights: time to celebrate, time to reflect, time to work harder?' Victoria University Human Rights Research 1-31

Committee on Economic, Social and Cultural Rights (CESCR) (1990) General Comment 3: The nature of States Parties' Obligations (Art 2, Para 1, of the Covenant) 14 December, E/1991/23

Committee on Economic, Social and Cultural Rights (CESCR) (2009) General Comment No 20: Non-discrimination in economic, social and cultural rights (art. 2, para. 2, of the International Covenant on Economic, Social and Cultural Rights) 2 July, $\mathrm{E} / \mathrm{C} 12 \mathrm{GC} / 20$

Committee on the Elimination of Discrimination against Women (2012) Concluding observations of the Committee on the Elimination of Discrimination against Women: New Zealand 27 July, CEDAW/C/NZL/CO/7

Constitutional Advisory Panel (2013) New Zealand's Constitution: A Report on a Conversation (He Kōtuinga Kōrero mō Te Kaupapa Ture o Aotearoa) New Zealand Government, November [Online] Available: www.ourconstitution.org.nz accessed 16 June 2015

Darke M (2011) 'Appendix: Recent New Zealand cases addressing ESC rights' in M Bedggood and K Gledhill (eds) Law into Action: Economic, Social and Cultural Rights in Aotearoa New Zealand Human Rights Foundation of Aotearoa, Auckland

Erdos D (2009) 'Judicial culture and the politicolegal opportunity structure:

explaining Bill of Rights legal impact in New Zealand' 34 (1) Law E Social Inquiry 95127

Felner E (2009) 'Closing the "escape hatch": a toolkit to monitor the progressive realization of economic, social and cultural rights' 1(3) Journal of Human Rights Practice 402-35

Geddis A (2013) 'I think National just broke our constitution' (blog) 17 May [Online] Available: http://pundit.co.nz/content/i-think-national-just-broke-our-constitution accessed 16 June 2015

Geiringer C and Palmer M S R (2007) 'Human rights and social policy in New Zealand' 12(30) Social Policy Journal of New Zealand 12 [Online] Available: http://papers.ssrn.com/abstract $=983041$

Hindle R (2013) The Human Rights Review Tribunal: Problems and Possibilities draft paper 
Human Rights Council (2014) Draft Report of the Working Group on the Universal Periodic Review: New Zealand 29 January, A/HRC/WG.6/18/L.1

Huscroft G and Rishworth P (eds) (1995) Rights and Freedoms Brookers, Wellington International Commission of Jurists (2008) Courts and the Legal Enforcement of Economic, Social and Cultural Rights: Comparative Experiences of Justiciability Geneva, [Online] Available: www.humanrights.ch/upload/pdf/080819_justiziabilitt_esc.pdf accessed 16 June 2015

Keith K (2013) ‘New Zealand and international law: 1963-2013’ 25 New Zealand Universities Law Review 718

Meikle K (2011) 'Economic, social and cultural rights: protection in Aotearoa New Zealand - an overview' in M Bedggood and K Gledhill (eds) (2011) Law into Action: Economic, Social and Cultural Rights in Aotearoa New Zealand Human Rights Foundation of Aotearoa, Auckland

Miller E and Sissons J (2013) 'A human right to collective bargaining?', paper presented at New Zealand Labour Lawyers Conference, 22 November

Ministry of Justice (2000) Re-evaluation of the Human Rights Protections in New Zealand Report to Associate Minister of Justice.

New Zealand Government (2014) New Zealand's Response to 2014 Universal Periodic Review Recommendations [Online] Available:

www.justice.govt.nz/publications/global-publications/u/united-nations-universalperiodic-review-2014-government-response-to-recommendations

Opie J (2012) 'A case for including economic, social and cultural rights in the New Zealand Bill of Rights Act 1990' 43 Victoria University of Wellington Law Review 471

Opie J (2014) 'Economic, social and cultural rights' New Zealand Law Journal 195

Palmer G (1984-85) 'A Bill of Rights for New Zealand: a white paper' 1 Australian Journal of Human Rights A6

Palmer G (2006) 'The Bill of Rights fifteen years on', keynote speech for Ministry of Justice Symposium on the New Zealand Bill of Rights Act 1990, Wellington, 10 February

Palmer G (2013) 'The Bill of Rights after twenty-one years' 11 New Zealand Journal of Public and International Law 257

Palmer M S R (2007) ‘New Zealand constitutional culture' 22 New Zealand Universities Law Review 565

Wilson M (2011) 'An account of the making of the Human Rights Amendment Act 19(2) Waikato Law Review 1 
* Margaret Wilson, Professor of Law, University of Waikato. Email: mwilson@waikato.ac.nz.

Judy McGregor, Professor and Head of School Social Science and Public Policy, Auckland University of Technology. Email: judy.mcgregor@aut.ac.nz.

Sylvia Bell, Former Principal Policy and Legal Analyst, New Zealand Human Rights Commission. Email: Sylvia.bell@aut.ac.nz

The research undertaken for this article is part of a Law Foundation funded Project on assessing the impact of New Zealand's ratification and state receptivity of the major international human rights treaties. 